\title{
Electrochemical Immunosensing of GOx-labeled CRP Antigen on Capture Antibody Monolayer Immobilized on Calixcrown-5 SAMs
}

\author{
Hye-Sook Jung, Kum-Soo Song, ${ }^{\dagger}$ and Taisun Kim ${ }^{*}$ \\ Department of Chemistry, Hallym University, Chuncheon 200-702, Korea. "E-mail: tskim@hallymackr \\ "Biochip Research Center, Biometrix Technology, Ine, Chuncheon 200-161, Korea \\ Received April 17, 2007
}

\begin{abstract}
Insulating effects on $\Lambda \mathrm{u}$ electrode according to the thickness and density of coated materials are well-known. To do electrochemical immunoassay reproducibly the glod electrode would be coated with self-assembled monolayers and antobodies. To get reproducibility, the antobody monolayer should be packed at highest density so that the amount of immobilized antibody at defined area should be the same. The calix[4]crown-5 SAMs could provide the basis for the antibodies to be immobilized reproducibly and at highest density. But the insulating effect would be highest too. We proved that the compactly packed protein monolayers on $\$ \Lambda \mathrm{Ms}$ inhibited the electron transfer by block the free shuttling of redox molecules. The inhibition was minimized by inserting redox molecules in between the proteins during immobilization process. In this paper, we demonstrated that the calix[4]crown-5 $\mathrm{S} \Lambda \mathrm{M}$ s would provide the protein monolayers with highest density and new method to minimize the insulating effect by inserted redox molecules in between the compactly packed protein monolayers.
\end{abstract}

Key Words : Glucose sensing, Calix[4]crown-5 SAMs, Molecular recognition, Insulating, Inserted redox molecules

\section{Introduction}

Glucose oxidase ( $\mathrm{GOx}$ ) is a redox-enzyme generating electrochemical signals by oxidizing the glucose in solution. Signal intensity is proportional to the concentration of the glucose present in solutions such as bloods. ${ }^{12}$ But when the glucose concentration is over $30 \mathrm{mM}$ the electrochemical signal becomes constant to specific value. So if we keep the glucose concentration over $30 \mathrm{mM}$ the electrochemical signal intensity is linearly proportional to the amount of the GOx present on the electrode. ${ }^{34}$ Recently, the interesting property of $\mathrm{GOx}$ is started to be used in sensing the amount of marker proteins in blood electrochemically: ${ }^{*-8}$

Electrochemical immunosensors are based on enzyme linked immunosorbent assays (ELISAs) and the signals are generated by redox enzymes attached to the proteins such as antibodies and marker proteins. Even though antibodies and marker proteins are interacted each other with high selectivity and affinity, both proteins are inert electrochemically. Therefore electrochemical immunosensing requires labeling the marker proteins for competitive immunoassay or secondary antibodies for immunoassay with redox enzymes such as GOx. ${ }^{911}$

In order to diagnose diseases precisely and at early stage, methods to get quantitative signals according to the concentration of marker proteins and to amplify signals have been under serious investigation these days. To increase the electrochemical signals, one research direction is to increase the density of immobilized capture proteins on the electrode surface and the other is to increase the amount of transferred electrons generated by enzymes such as $\mathrm{GOx}$ to the electrode surface ${ }^{5-8}$
The specific biotin-streptavidin interaction is a wellknown method of immobilizing antibody on electrode surface. Several other methods have been used to effectively modify the electrode surface with capture antibody. ${ }^{12.13}$ The amount of immobilized capture antibody should be as high as possible to get the electrochemical signal as high as possible. We recently presented a noble method of highdensity protein immobilization on self-assembled monolayer (SAM) of calix [4]crown-5 derivative (Fig. 1) on gold substrates (Fig. 3a) without activity loss or inconect orientation of the capture proteins. ${ }^{1+17}$ According to the method, capture antibodies were immobilized on the $\mathrm{SAM}$ surface with high density and activity without any modification (Fig. 3b).

In this paper, we used electrochemical method to show that the density of immobilized proteins was high enough to intervene the transfer of redox molecules between the enzymes and electrodes because the protein monolayer on SAMs of calix[4]crown-5 derivative covered the electrode surface completely not to leave enough area for the redox

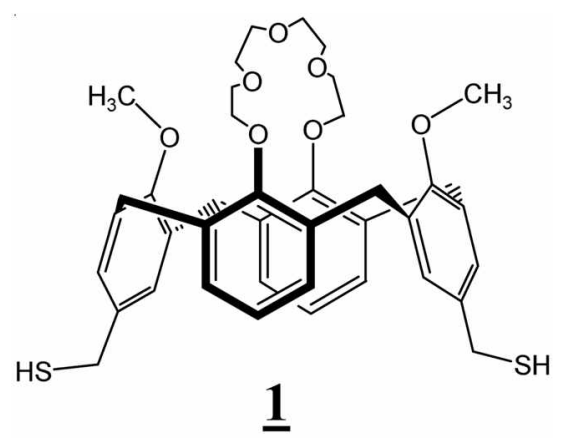

Figure 1. The structure of calix[4]crown-5 derivative. 
molecules to approach close to the electrode surface for electron transfer. To make the electron transfer more reliable we developed new method for redox molecules to be fixed in between immobilized proteins during immobilization process and the results based on cyclovoltammetry would be presented.

\section{Experimental Section}

Chemicals and reagents. Calix[4]crown-5 derivative (1) was prepared according to the methods previously described. $^{18}$ Glucose oxidase (E.C. 1.1.3.4. 179,000 units/g, type $\mathrm{X}$-S from Aspergillus niger, GOx) and $\mathrm{D}-(+)$ glucose, Glutaraldehyde were purchased from Sigma. C-reactive protein (CRP) and capture antibody were purchased from Scripps laboratories Inc. Ferrocene carboxylic acid was purchased from Aldrich. Sephadex ${ }^{\mathrm{TM}} \mathrm{G}-50$ gel column was purchased form Amersham Pharmacia Biotech. All other chemicals were of analytical grade and used without further purification. Doubly distilled and deionized water with specific resistance over $18 \mathrm{M} \Omega \cdot \mathrm{cm}$ was used throughout this work.

Instrumentation. Electrochemical measurements were performed with an AFRDE5 Bi-potentiostat electrochemical analyzer (Pine Instrument, IN). A standard three-electrode configuration with a platinum gauze counter electrode, $\mathrm{Ag} /$ $\mathrm{AgCl}(3 \mathrm{M} \mathrm{KCl})$ reference electrode and $\mathrm{Au}\left(0.06 \mathrm{~cm}^{2}\right)$ working electrode were used. All experiments were performed at room temperature $\left(25 \pm 2{ }^{\circ} \mathrm{C}\right)$. The electrolyte solutions were dideoxygenated with argon bubbling for 20 $\min$ before each voltammetric run.

Preparation of calix[4]crown-5 SAMs (Fig. 2a). The Au electrode $\left(0.06 \mathrm{~cm}^{2}\right)$ was cleaned in freshly prepared piranha solution (3:1 mixture of concentrated $\mathrm{H}_{2} \mathrm{SO}_{4}$ and $30 \%$ $\mathrm{H}_{2} \mathrm{O}_{2}$ ). After washing with deionized water, the Au electrode

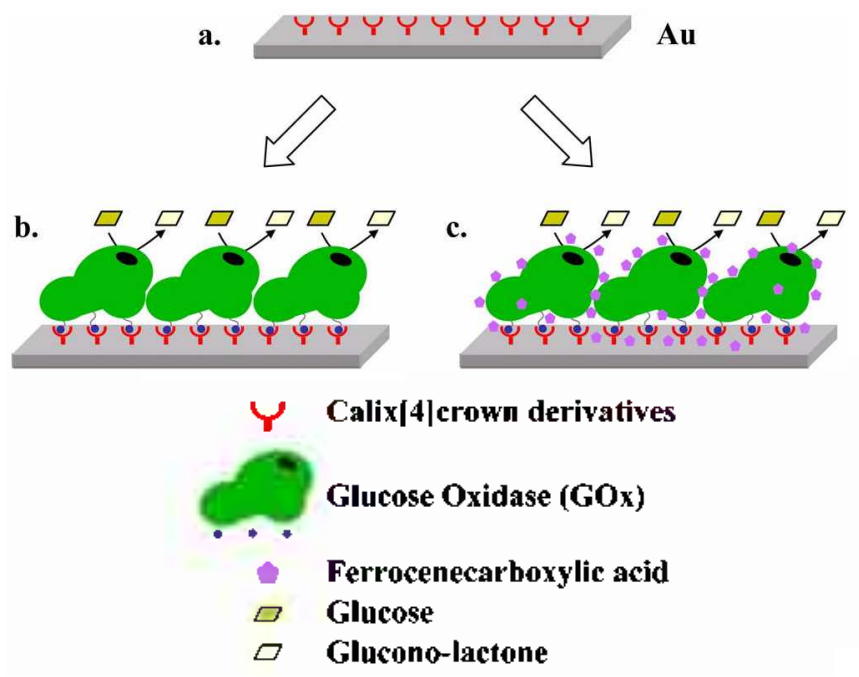

Figure 2. Schematic representation of preparing GOx monolayer on $\mathrm{Au}$ electrode: (a) Calixcrown-5 derivatives SAMs on $\mathrm{Au}$ clectrode. (b) The glucose oxidase imınobilized without redox molecules (c) The glucose oxidase immobilized with redox molecules. Rodox molecules is ferrocene carboxylic acid, $0.3 \mathrm{mM}$. was dried under a stream of $\mathrm{N}_{2}$ gas. The clean Au electrode was coated in $3 \mathrm{mM}$ calix[4]crown-5 derivative (1) solution for $4 \mathrm{hr}$ and rinsing sequentially with $\mathrm{CHCl}_{3}$, acetone, ethanol, and $150 \mathrm{mM} \mathrm{NaCl}$ solution. $\mathrm{GOx}$ can be readily immobilized on Calix[4]crown-5 SAMs.

Preparation of GOx monolayer on calix[4]crown-5 SAMs with and without redox molecules (Fig. 2b, 2c). To the solution of $1 \mathrm{mg} \mathrm{GOx}$ dissolved in $1 \mathrm{~mL}$ of $150 \mathrm{mM}$ $\mathrm{NaCl}$ (in PBS buffer) was dipped calix[4]crown-5 SAMs (Fig. 2a) and incubated at room temperature for $3 \mathrm{~h}$. The resulting GOx monolayer (Fig. 2b) was then washed twice with $150 \mathrm{mM} \mathrm{NaCl}$ (in PBS buffer) solution at room temperature. The GOx monolayer with redox molecules (Fig. 2c) was prepared according to the same method but in the presence of $0.3 \mathrm{mM}$ of ferrocene carboxylic acid in the $\mathrm{GOx}$ solution during immobilization.

Preparation of CRP antibody monolayer with and without redox molecules (Fig. 3b). To the solution of 6 ug $\mathrm{CRP}$ antibody dissolved in $\mathrm{I} \mathrm{mL}$ of $150 \mathrm{mM} \mathrm{NaCl}$ (in PBS buffer) solution with and without $0.3 \mathrm{mM}$ ferrocene carboxylic acid, was dipped calixcrown-5 SAMs (Fig. 3a) and incubated at room temperature for $3 \mathrm{~h}$. The CRP antibody monolayer (Fig. 3b) was then washed twice with $150 \mathrm{mM}$ $\mathrm{NaCl}$ (in PBS buffer) solution at room temperature.

Conjugated CRP antigen-GOx. CRP antigen was conjugated with GOx through the imine-forming, amine-aldehyde

a.

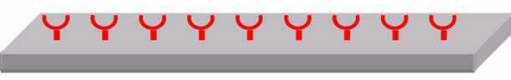

b.

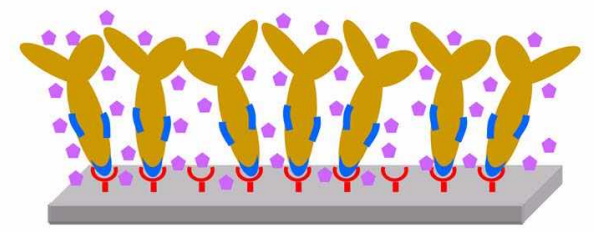

c.
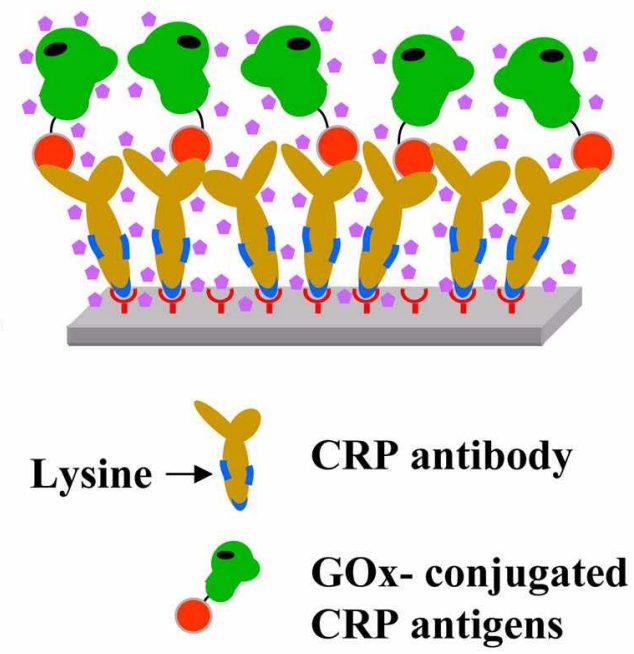

Figure 3. Schematic representation of preparing competitive immunosensor using CRP antibody monolayer: (a) Calix[4]crown5 SAMs on Au electrode (b) The CRP antibody immobilized with and without redox molecules (ferrocenecarboxylic acid) (c) GOxCRP Ag conjugates reacted and completely covered CRP antibody monolayer. 
reaction. The solutions of $108.6 \mathrm{uL}$ of $0.1 \mathrm{mM}$ carbonate buffer $(\mathrm{pH}=8.5-9)$ and $240 \mathrm{uL}$ of $\mathrm{GOx}(10 \mathrm{mg} / \mathrm{mL}$ in 150 $\mathrm{mM} \mathrm{NaCl})$ and $87.4 \mathrm{uL}$ of CRP antigen $(1 \mathrm{mg} / \mathrm{mL}$ in 150 $\mathrm{mM} \mathrm{NaCl}$ ) were mixed and stirred at room temperature. To the reaction mixture was added dropwise $0.1 \%(\mathrm{v} / \mathrm{v})$ glutaraldehyde $(67.7 \mathrm{umol})$ for $30 \mathrm{~min}$. The reaction mixture was slowly stirred at room temperature for $90 \mathrm{~min}$. The reaction product was purified through lipophilic gel-permeation chromatography (Sephade ${ }^{\mathrm{TM}} \mathrm{G}-50$ ) using Ix PBS buffer as the eluent. Purity and degree of modification were determined by using UV/Vis spectroscopy. ${ }^{19-22}$

Immunoassay of CRP antibody-antigen interaction (Fig. 3 c), 40 ug of CRP antigen-GOx conjugate dissolved in $1 \mathrm{~mL}$ of $150 \mathrm{mM} \mathrm{NaCl}$ (in PBS buffer) with and without 0.3 $\mathrm{mM}$ ferrocene carboxylic acid (redox molecules) was dipped CRP antibody monolayer. The immobilized CRP antibody and conjugate were reacted at $37^{\circ} \mathrm{C}$ for $1 \mathrm{~h}$. The monolayer prepared (Fig. 3c) was then washed twice with $150 \mathrm{mM}$ $\mathrm{NaCl}$ (in PBS buffer) at room temperature and was used to electrochemical detection.

Detection. Cyclic voltammograms of GOx monolayer and $\mathrm{CRP}$ antibody monolayer reacted with the GOx-conjugate were measured. Cyclic voltammograms were obtained for both electrodes in the presence of $40 \mathrm{mM}$ glucose between $0 \mathrm{~V}$ and $+0.6 \mathrm{~V}$ vs. $\mathrm{Ag} / \mathrm{AgCl}$ at the speed of $10 \mathrm{mV} / \mathrm{s}$. Gray voltammograms were obtained using same electrodes in the absence of glucose. All curves were obtained in a dideoxygenated $150 \mathrm{mM} \mathrm{NaCl}(\mathrm{pH}=6.8)$ solution containing 0.3 $\mathrm{mM}$ ferrocene carboxylic acid at $10 \mathrm{mV} / \mathrm{s}$ and the electrochemical signals were measured and displayed in $\mathrm{uA} / \mathrm{cm}^{2}$ scales. All experiments were performed at $25 \pm 0.5^{\circ} \mathrm{C}$

\section{Results and Discussion}

Both GOx and CRP antibody monolayers were prepared according to previously reported protein immobilization method (Fig. 2 and 3) on calix[4]crown-5 SAMs. ${ }^{15}$ GOx monolayers on Au were prepared by dipping calix[4]crown5 SAM (Fig. 2a) in the GOx solution for 3 hrs and used for working electrode. Electrochemical measurement vs. Ag/ $\mathrm{AgCl}$ reference electrode was done in the deoxygenated 150 $\mathrm{mM} \mathrm{NaCl}$ solution containing $0.3 \mathrm{mM}$ ferrocene carboxylic acid. Cyclic voltammograms (CV's) were obtained between $0 \mathrm{~V}$ and $+0.6 \mathrm{~V}$ at the speed of $10 \mathrm{mV} / \mathrm{s}$. Dark and grey CV's of Figure $4 \mathrm{a}$ were obtained in the presence and absence of 40 $\mathrm{mM}$ glucose. Three independent measurements revealed that dark $\mathrm{CVs}$ showed about $22 \mathrm{uA} / \mathrm{cm}^{2}$ higher anodic current compared to grey CV's. Interestingly, black CVs showed anodic currents continuously increased and those phenomena occurred only when the shuttling of redox molecules to the electrode surface was disturbed or the electron transfer was disturbed. Considering the materials we used to prepare the electrodes and electrolytes, the only material that could interrupt the redox molecules transferred to the electrode surface would be GOx molecules compactly packed on the electrode. One solution would be to leave enough space in between the GOx molecules for redox

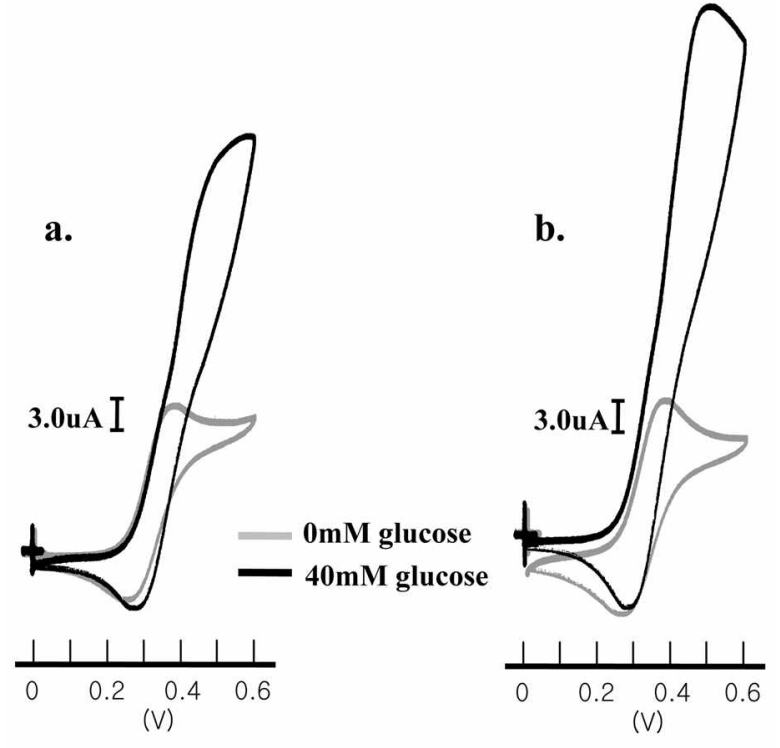

c.

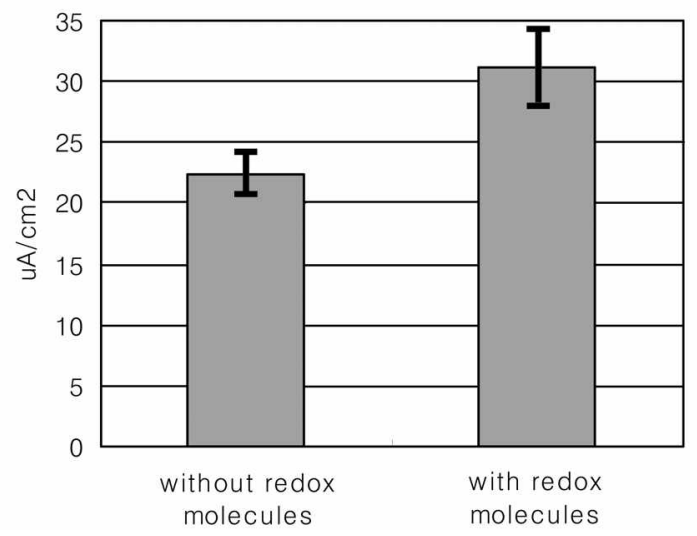

Figure 4. Typical cyclic voltammetric signal traces for GOx monolayer on the Calix[4]crown-5 SAMs: (a) without ferrocenccarboxylic acid (b) with $0.3 \mathrm{mM}$ ferrocene carboxylic acid (c) The effect of presence and absence of ferrocenecarboxylic acid in the immobilization solutions. Nll curves were registered in a dideoxygenated $150 \mathrm{mM} \mathrm{NaCl}(\mathrm{pH}=6.8)$ solution. Potential scan rate was 10 $\mathrm{mV} / \mathrm{s}$. Gray voltammograms in the absence of glucose, black voltammograms in the presence of $40 \mathrm{mM}$ glucose.

molecules to shuttle more freely and the other would be to place the redox molecules between the GOx molecules so the electrons could be transferred freely. First solution was well known to be very hard to accomplish because of the interaction between molecules during self-assembly of the GOx molecules. Therefore, we decided to place the redox molecules between the GOx molecules during immobilization on calix[4]crown- 5 SAMs.

As the proteins were known to be compactly packed on calix[4]crown-5 SAMs, we prepared working electrodes of redox molecule-inserted GOx monolayer (Fig. 2c) by simply dipping the electrodes in GOx solution containing $0.3 \mathrm{mM}$ ferrocene carboxylic acid. Same concentration of redox molecules were used for electrochemical measurement and for immobilization so that the redox molecules packed in between the immobilized GOx molecules would help to 


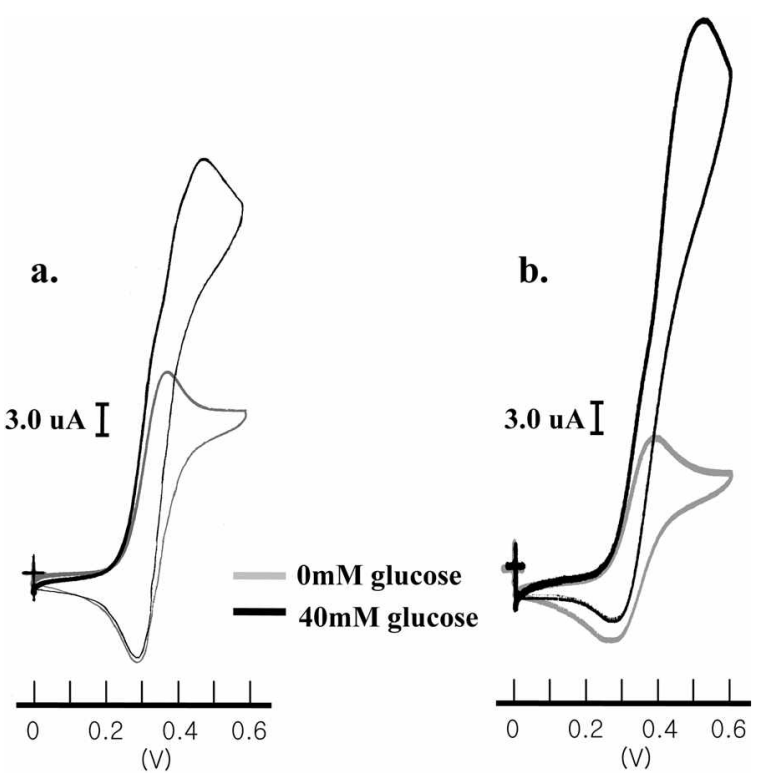

c.

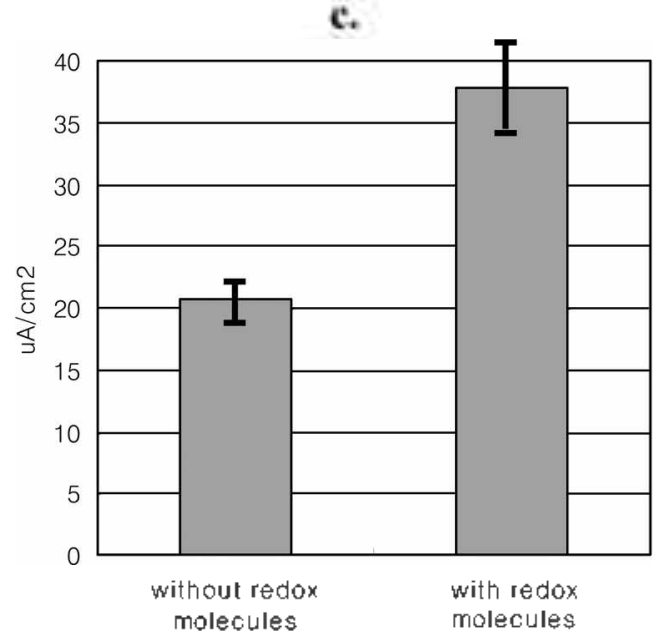

Figure 5. Typical CVS for the electrodes modified with CRP antibody monolayer interacted to CRP-GOx conjugates: (a) monolayer formed without ferrocene carboxylic acid and (b) with 0.3 ImM ferrocene carboxylic acid (c) Signal amplification by the effect of inserted redox molecules. All curves were registered in a didcoxygenated $150 \mathrm{mM} \mathrm{NaCl}(\mathrm{pH}=6.8)$ solution. Potential scan rate was $10 \mathrm{mV} / \mathrm{s}$. Gray CVs obtained in the absence of glucosc, black CVs in the presence of $40 \mathrm{mM}$ glucose.

make the electron transfer more freely. Electrodes prepared by the new method gave us much improved electrochemical signals (Fig. 4b) when they were exposed to the same condition to get the grey data in Figure 4a. The electrochemical signals at $+0.5 \mathrm{~V}$ with $40 \mathrm{mM}$ glucose were increased almost $40 \%$ and the signals without glucose were not changed significantly. The results assured us that redox molecules could be inserted in the compactly packed GOx monolayer and the concentration of inserted redox molecules was not changed significantly during electrochemical measurement only if the same concentration of redox molecules was used in insertion process and in electrolyte.

The results encouraged us to apply the new method to competitive electrochemical immunoassay. The CRP anti- body electrodes with and without inserted redox molecules were prepared on the gold electrode modified with calix[4]crown-5 monolayer. After all antibody molecules on antibody monolayer were interacted to GOx-modified antigens, Figure $3 \mathrm{~b}$ shows $\mathrm{CVs}$ taken in the presence and absence of $40 \mathrm{mM}$ glucose. Comparing the data with and without inserted redox molecules (Fig. 5a and $5 b$ ) we could tell the inserted redox molecules reduced significantly the effect of the well-packed antibodies blocking the electron transfer and the electrochemical signals at $+0.5 \mathrm{~V}$ with 40 $\mathrm{mM}$ glucose were increased almost $80 \%$. The electrochemical measurements were done once for each and every CV's for the interaction of CRP antibody and antigen. Figure 4 and 5 clearly showed the covered proteins on electrode such as GOx and CRP antibody interrupted the electron transfer and it could be reduced completely by inserting redox molecules in between the proteins during immobilization process. As was mentioned in previous paper, these results clearly showed that the proteins immobilized and compactly packed on calix[4]crown-5 SAMs without leaving enough area for inserted redox molecules to escape from the protein monolayers during measurement and afterwards.

\section{Conclusions}

We demonstrated that proteins could be immobilized and packed compactly on the self-assembled monolayers of calix[4]crown-5 derivative (1). The compact packing of proteins were examined and proved according to the electrochemical methods. The CVs of Figure 4a and 5a obtained by the electrodes modified with proteins clearly showed that the electron transfer was interrupted by the closely packed proteins. And according to the CVs of Figure $4 b$ and $5 b$ the redox molecules can be inserted and stayed in between the closely packed proteins during measurement only if the concentration of redox molecules was kept constant during immobilization and measurement steps. The electrochemical data obtained before and after the insertion of redox molecules were changed significantly. The results clearly showed that the compactly packed proteins could block the free shuttling of redox molecules to the electrode surface and the new method of inserting redox molecules could minimize the effect.

We showed new method of amplifying electrochemical signals by reducing the insulating effects on the electrode modified by SAMs of calix[4]crown derivatives (1). We are currently working on the possible application of the method to manufacture commercial immunosensors by increasing the detection limits of various antigens on antibody monolayers modified on calix[4]crown- 5 SAMs.

Acknowledgment. This research was supported by Hallym University Research Fund (HRF-1999-08).

\section{References}

I. Shin, J. H.; Yoon, S. Y.; Yoon, I. J.; Choi, S. H.; Lee, S. D.; Nam, 
H.; Cha, G. S. Sensors and Actutors B 1998, 50, 19.

2. Cui, G.; Yoo, J. H.; Woo, B. W.; Kim, S. S.; Cha, G. S.; Nam, H. Talanta 2001, 54, 1105.

3. Riklin, A.; Willer, I, Anal. Chem 1995, 67,4118.

4. Yoon, H. C.; Hong, M., Y.; Kim, H. S. Anal. Biochem. 2000, 282, $12 \mathrm{l}$.

5. Darain, F.; Park, D. S.; Shim, Y. B. Biosents. Bioelectron. 2003, 18 , 773.

6. Darain, F.; Park, D. S.; Park, J. S.; Chang. S. C.; Shim, Y. B. Biosens. Bioelectron, 2005, 20, 1780.

7. Ionescu, R. E.; Gondarn, C.; Consnier, S.; Gheber, L. A.; Marks, R. S. Talanta $2005,66,15$.

8. Zeravik, J.; Ruzgas, T.; Frànek, M. Biosents. Bioelectron. 2003, 18,1321 .

9. Tiefenauer, L. X.; Kossek, S.; Padeste, C.; Thiebaud, P. Biosents, Bioelectron. 1997, 12(3), 213.

10. Wendzinski, F.; Grundig, B.; Rennerberg, R.; Spener, F. Biosens. Bioelectron. 1997, 12(1), 43 .

1I. Ghindilis, A.; Krishana, R.; Atanasov, P.; Wilkins, E. Biosens, Bioelectron. 1997, $12(5), 415$.

12. Yoshio, O.; Kenichi, N.; Yukio, S.; Mamoru, S.; Takashi, M.
Biochent. 1998, 37, 5666 .

13. Vender, A. V.; Evtushenko, O. A.; Baykov, A. A. Aftal. Biochent. 1990, 191,65 .

14. Kubo, Y;; Maeda, S.; Tokita, S.; Kubo, M. Nature 382, 522, 1996.

15. Lee, Y. S.; Lee, E. K.; Cho, Y. W.; Matsui, T; Kang, I. C.; Kim, T. S.; Han, M. H. Proteomics 2003, 3, 2289.

16. Choi, S.; Choi, E. Y.; Kim, D. J.; Kim, J. H.; Kim, T. S.; Oh, S. W. Clinica Chimica Acta 2004, 339, 147.

17. Oh, S. W.; Moon, J. D.; Lim, H. J.; Park, S. Y.; Kim, T. S.; Park, J. B.; Han, M. H.; Snyder, M.; Choi, E. Y. The FASEB Joumal 2005. 19,1335 .

18. Kìm, T. S. Proteogen, US Patent no. 6, 485, 984 Bl, Nov 26 , 2002.

19. Avrameas, S.; Ternynck, T.; Guesdon, J. L. Immtnol. 1978, $8($ Stppl. 7), 7

20. Principles and Practice of Immunoassay; Price, C. P.; Newman, D. J., Eds.; Stockion Press: New York, 1991.

2l. Crowther, J. R, ELISA Theory and Pratice; Humana Press Inc.: 1996.

22. Ryoo, H.; Kim, Y.; Lee, J.; Shin, W.; Myung. N.; Hong, H.-G. Bull. Korean Chem. Soc. 2006, 27,672. 